\title{
Studi Deskriptif: Sikap, Pengawasan Keluarga, Tingkat Pengetahuan dan Upaya Pengendalian Hipertensi Pada Lansia
}

\author{
Yessi Angga Novitasari ${ }^{1}$, Novita Nirmalasari ${ }^{2 *}$ \\ ${ }^{1,2}$ Universitas Jenderal Achmad Yani Yogyakarta \\ *Email: novitanirmalasari@gmail.com
}

\begin{abstract}
Background: Elderly is a decrease in cardiovascular function. Sstructural and functional changes occur in the peripheral vascular system responsible for variations in blood pressure. The study aims at finding out attitude, family supervision, level of knowledge, and efforts to control hypertension in working area Puskesmas Saptosari Gunungkidul. Method: The study was descriptive research with cross-sectional. Samples were selected using a purposive sampling. The number of the sample 38 repondent. The research instrument used a questionnaire. The data analysis used was univariate. Result: The majority of women (94.7\%), aged 60-70 years (84.2\%), and hypertension stage I (68.4\%). Most of the attitudes have the right attitude (94,7\%), family supervision (89,5\%), and inadequate level of knowledge (76,3\%). In controlling efforts, most were in a good category (94,7\%). Conclusion: Almost all respondents have the right attitude and supervision from the family. Even though they have an inadequate level of knowledge, control efforts are mostly reasonable.
\end{abstract}

Keywords: attitude, efforts to control hypertension, family supervision, level of knowledge

\section{PENDAHULUAN}

Usia Harapan Hidup (UHH) penduduk Indonesia yang tinggi merupakan cerminan dari meningkatnya status kesehatan lansia (Kemenkes RI, 2016). Sejumlah tiga provinsi pada tahun 2017 memiliki persentase lansia terbesar yaitu Daerah Istimewa Yogyakarta (DIY) sejumlah 13,81\%, Jawa Tengah sejumlah 12,59 dan Jawa Timur sejumlah 12,25\% (Kemenkes RI, 2018).

Lansia merupakan rentang kehidupan yang berada pada fase penurunan kesehatan salah satunya adalah penurunan fungsi kardiovaskuler. Pembuluh darah perifer kehilangan elastisitas jaringan ikat dan mengalami aterosklerosis. Hal tersebut menyebabkan tekanan darah sistolik meningkat sehingga terjadi peningkatan tekanan darah atau hipertensi (Sudoyo dkk, 2009).

Prevalensi hipertensi DIY berada pada urutan ke 12 dari seluruh provinsi di Indonesia (Kemenkes RI, 2018). Penyakit ini ini juga dikenal sebagai silent killer karena terkadang tidak memiliki gejala.
Gejala yang dapat muncul seperti sakit kepala, mudah lelah dan vertigo. Komplikasi hipertensi dapat memunculkan berbagai seperti penyakit jantung, stroke, gagal ginjal dan retinopati (Kemenkes RI, 2016). Komplikasi tersebut akan menyebabkan kematian setiap tahunnya di seluruh dunia. Sejumlah $45 \%$ kematian akibat penyakit jantung dan $51 \%$ kematian akibat penyakit stroke disebabkan dari penyakit hipertensi (Kemenkes RI, 2018).

Penatalaksanaan hipertensi dapat melalui terapi farmakologi dan non farmakologi. Penatalaksanaan hipertensi dengan non-farmakologi antara lain dengan menerapkan pola hidup sehat seperti mengurangi konsumsi garam dan alkohol, berolahraga, dan tidak merokok (Kemenkes RI, 2013). Pengukuran tekanan darah secara berkala dapat dilakukan untuk menjaga tekanan darah. Penatalaksanaan farmakologi dilakukan dengan konsumsi obat-obatan. Kepatuhan minum obat diperlukan dalam pengobatan hipertensi (Zaenurrohmah \& 
Rachmayanti, 2017). Penelitian sebelumnya di lokasi yang sama menunjukkan bahwa upaya pengendalian hipertensi belum maksimal. Hal ini dibuktikan dengan jumlah lansia yang tidak mengetahui atau memahami tentang hipertensi dan upaya pengendaliannya sebesar 67\% (Sumarhaeni, 2010).

Studi pendahuluan yang dilakukan pada bulan Februari 2020 di Puskesmas Saptosari didapatkan bahwa Kelurahan Desa Planjan merupakan kelurahan dengan jumlah kasus hipertensi tertinggi pada lansia di Kecamatan Saptosari. Hal ini ditunjukkan dengan kasus hipertensi di Kelurahan Desa Planjan sebanyak 85 kasus pada bulan Februari 2020. Hasil wawancara dan observasi dengan lima lansia di Posyandu lansia didapatkan data bahwa $100 \%$ atau seluruh lansia dalam memelihara kesehatan, mereka tidak datang rutin ke posyandu untuk kontrol tekanan darah. Berdasarkan uraian latar belakang di atas dapat dirumuskan masalah dalam penelitian ini adalah Bagaimana gambaran sikap, pengawasan keluarga, tingkat pengetahuan dan upaya pengendalian hipertensi pada lansia di wilayah kerja Puskesmas Saptosari Gunungkidul.

Tujuan penelitian ini untuk mengetahui gambaran sikap, pengawasan keluarga, tingkat pengetahuan dan upaya dalam mengendalikan hipertensi pada lansia di wilayah kerja Puskesmas Saptosari Gunungkidul.

\section{METODE PENELITIAN}

Penelitian ini merupakan penelitian deskripstif kuantitatif non eksperimen. Lokasi penelitian di Wilayah Kerja Puskesmas Saptosari Gunungkidul. Pengambilan data dilakukan bulan Maret sampai bulan April 2020 dengan teknik purposive sampling. Sejumlah 38 responden dipilih berdasarkan kriteria inklusi dan eksklusi. Kriteria inklusi meliputi lansia dengan hipertensi berdasarkan diagnosis dokter dan dapat berkomunikasi dengan baik. Kriteria eksklusi yaitu lansia dengan gangguan kejiwaan. Variabel dalam penelitian ini adalah variabel univariat. Alat pengumpulan data yang digunakan adalah lembar data karakteristik responden, kuesioner sikap, kuesioner pengawasan keluarga, kuesioner tingkat pengetahuan, dan kuesioner upaya pengendalian hipertensi. Pengambilan data dilakukan langsung oleh peneliti kepada responden secara door to door. Pengisian kuesioner dilakukan responden dibantu keluarga atau peneliti.

Uji validitas instrumen dilakukan dengan menggunakan korelasi product moment person, sedangkan uji reabilitas menggunakan teknik Alpha Cronbach. Hasil uji validitas adalah sikap penderita $(0,814)$, pengawasan dari pihak keluarga $(0,792)$, tingkat pengetahuan $(0,790)$, dan upaya pengendalian hipertensi $(0,827)$ hasilnya lebih dari nilai $r$ tabel yaitu $(0,707)$ sehingga dinyatakan valid. Seluruh instrumen juga reliabel dengan hasil 0,623, maka seluruh pertanyaan sikap, pengawasan keluarga, tingkat pengetahuan dan upaya pengendalian dinyatakan reliabel (Dalyoko, 2010). Data yang sudah terkumpul kemudian dilakukan editing, coding, entry, cleaning dan tabulasi. Analisa data yang digunakan yaitu analisa data deskriptif menggunakan ukuran sebaran data dalam frekuensi dan persentase.

\section{HASIL PENELITIAN}

Penelitian dilakukan pada 38 lansia yang menderita hipertensi di wilayah kerja 
Puskesmas Saptosari Gunungkidul. Hasil penelitian disajikan pada tabel berikut ini.

Tabel 1. Karakteristik Responden $(\mathrm{n}=38)$

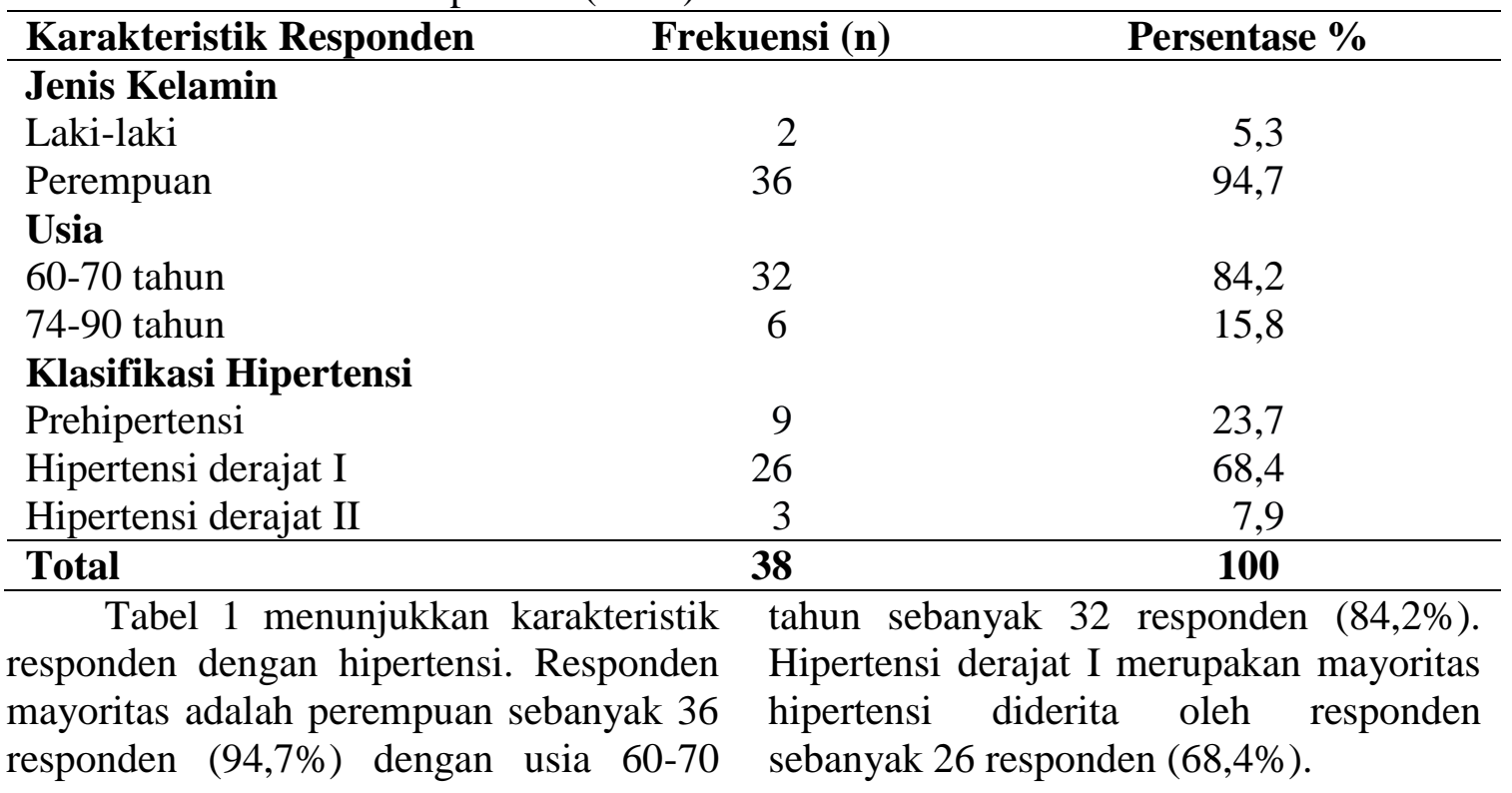

Tabel 2. Distribusi Frekuensi Responden Berdasarkan Sikap Penderita Hipertensi, Pengawasan Keluarga, Tingkat Pengetahuan, dan Upaya Pengendalian Hipertensi $(\mathrm{N}=38)$

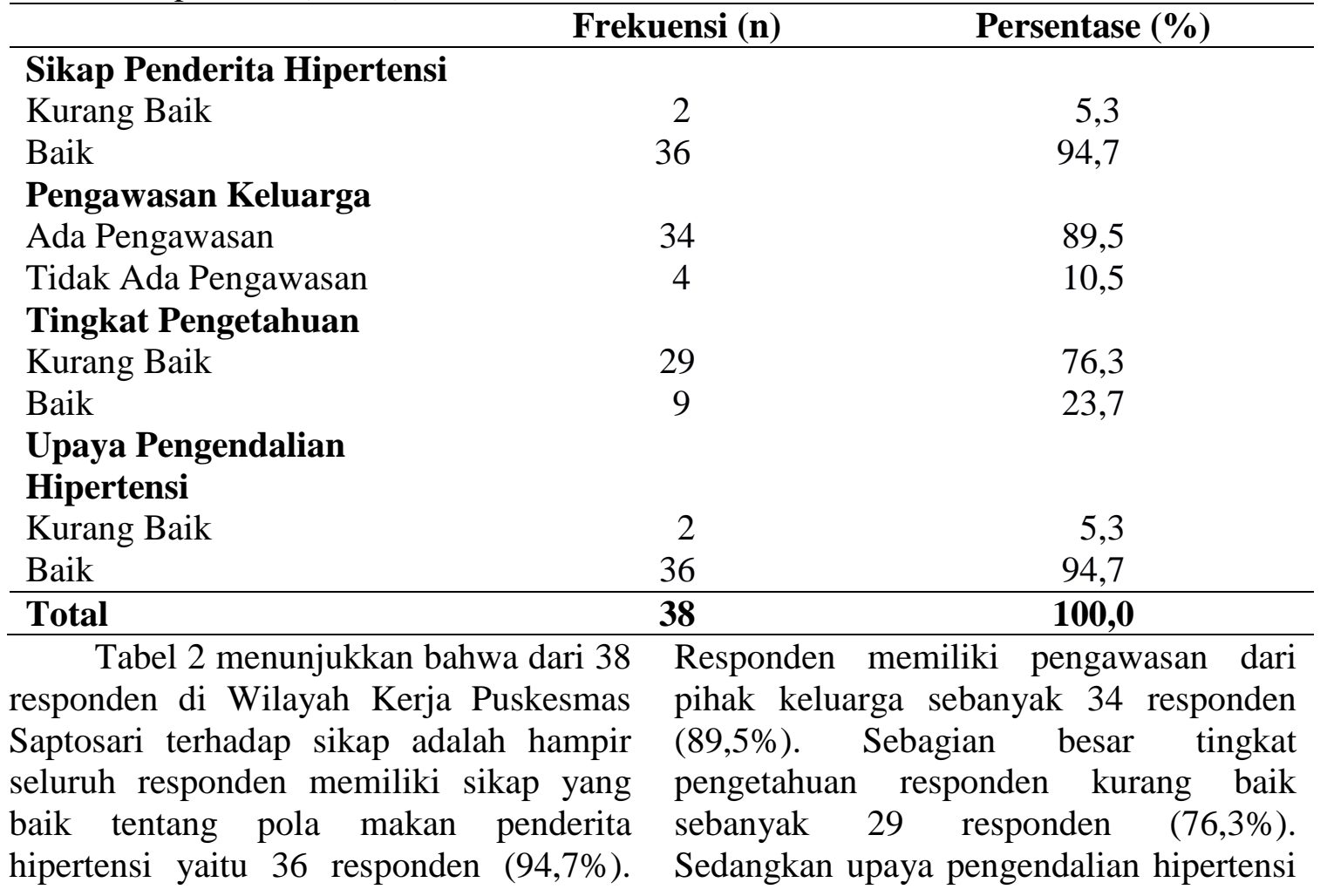


sebagian besar baik sejumlah 36 responden $(94,7 \%)$.

\section{PEMBAHASAN}

Hasil penelitian ini menunjukkan mayoritas lansia adalah perempuan. Hal ini sesuai dengan sebuah penelitian yang menunjukkan mayoritas lansia hipertensi adalah perempuan. Jenis kelamin perempuan lebih berisiko memiliki hipertensi dibandingkan laki-laki saat berusia lebih dari 65 tahun (Agrina, Rini, \& Hairitama, 2011; Nainggolan, Armiyati, $\&$ Supriyono, 2012). Namun ada pendapat berbeda yang menunjukkan bahwa jenis kelamin laki-laki dan perempuan memiliki risiko yang sama dalam menderita hipertensi (Kuswandono, 2019). Hormon estrogen yang dimiliki wanita berfungsi memelihara struktur normal pembuluh darah. Penurunan produksi estrogen ketika menopause menyebabkan penurunan fungsi pemeliharaan struktur pembuluh darah, sehingga lebih rentan terhadap penyakit hipertensi (Nainggolan et al., 2012).

Penelitian yang dilakukan Imran (2017) diperoleh hasil yang sama bahwa mayoritas lansia yang mengalami hipertensi berusia lebih dari 51 tahun (Agrina et al., 2011; Bacha \& Abera, 2019). Lansia merupakan rentang kehidupan yang berada pada fase penurunan kesehatan salah satunya adalah penurunan fungsi kardiovaskuler. Perubahan struktural dan fungsional pembuluh darah perifer seperti hilangnya elastisitas jaringan ikat dan aterosklerosis mengakibatkan perubahan tekanan darah. Hal ini dapat menyebabkan hipertensi (Sudoyo dkk, 2009)

Hasil penelitian didapatkan data bahwa mayoritas responden menderita hipertensi derajat I. Hal ini sejalan dengan penelitian di Puskesmas Tagulandung Kabupaten Sitaro yang menyatakan bahwa sebagian besar responden memiliki peran keluarga yang baik dan memiliki hipertensi derajat I. Hal ini membuktikan bahwa peran keluarga yang baik akan memberikan informasi tentang penyakit hipertensi sehingga dapat berperan dalam merawat anggota yang sakit (Matheos, Bidjuni, \& Rottie, 2018).

Hasil penelitian menyebutkan bahwa upaya dalam pengendalian hipertensi berada pada kategori baik. Hal ini sesuai dengan penelitian yang menyebutkan bahwa mayoritas perilaku kesehatan responden dalam kategori sikap positif atau baik. Sikap merupakan variabel yang paling dominan terhadap perilaku diet hipertensi (Heriyadi, Hasballah, \& Tahlil, 2017; Rahmah, 2019). Sikap merupakan predisposisi terhadap tindakan suatu perilaku kesehatan (Sunaryo, 2014). Upaya pengendalian hipertensi dipengaruhi oleh sikap terhadap penyakit hipertensi (Heriyadi et al., 2017).

Hasil penelitian ini sejalan dengan penelitian pada 33 responden yang menunjukkan bahwa mayoritas responden mendapat dukungan dari keluarga (Cahyawaty, 2017). Pengawasan dari keluarga berupa dukungan sangat penting bagi lansia dalam upaya pengendalian hipertensi. Keluarga berperan dalam perawatan kesehatan keluarga yang saling berkaitan dan saling mempengaruhi antar anggota keluarga. Hal ini dimulai dari peningkatan kesehatan, pencegahan, pengobatan, dan rehabilitasi. Dukungan keluarga pada pasien hipertensi dibutuhkan selama sakit. Pengawasan keluarga kepada penderita hipertensi dapat diberikan dalam memberikan diet hipertensi untuk mencegah atau 
mengendalikan hipertensi. Hal lain yang dapat dilakukan yaitu menganjurkan untuk berolahraga ataupun datang rutin ke posyandu (Dalyoko, Kusumawati, \& Ambarwati, 2011).

Hasil penelitian menunjukkan bahwa sebagian besar responden memiliki tingkat pengetahuan kurang baik. Sebagian besar lansia hanya mengetahui faktor pencetus hipertensi dari pola makan seperti mengkonsumsi daging kambing dan garam berlebih dapat menyebabkan hipertensi. Lansia tidak memahami bahwa faktor resiko hipertensi dapat berasal faktor genetik, usia, obesitas dan pola hidup sehat. Sebagian besar upaya pengendalian hipertensi sudah baik seperti dalam mengendalikan pola makan yang kurang baik bagi penderita hipertensi (Dalyoko et al., 2011). Tingkat pendidikan tinggi juga mempengaruhi tingkat pengetahuan seseorang. Pendidikan yang rendah akan mempengaruhi pengetahuan seseorang dalam menyikapi suatu masalah (Bacha \& Abera, 2019).

Penelitian lain menunjukkan bahwa tindakan pengendalian sebagian besar dalam kategori baik sebanyak 36 responden $(76,6 \%)$ dan kategori cukup sebanyak 11 responden $(23,4 \%)$. Upaya pengendalian yang baik yaitu dengan tindakan memodifikasi makanan dan aktivitas fisik. Pengendalian hipertensi dalam bentuk memodifikasi pola makan yaitu dengan mengurangi asupan garam berlebih. Aktivitas fisik yang dapat dilakukan berolahraga secara teratur. Pemantauan tekanan darah secara berkala juga dapat dilakukan sebagai upaya dalam mengendalikan hipertensi (Zaenurrohmah \& Rachmayanti, 2017).

\section{KESIMPULAN DAN SARAN}

Gambaran sikap lansia yaitu hampir seluruh responden memiliki sikap yang baik dengan gambaran ada pengawasan dari pihak keluarga dan sebagian besar memiliki upaya pengendalian yang baik. Akan tetapi tingkat pengetahuan responden sebagian besar kurang baik. Sebagian besar lansia kurang mengetahui faktor pencetus hipertensi, yang mereka tahu hanya konsumsi daging kambing dan konsumsi garam berlebih dapat menyebabkan hipertensi. Sedangkan faktor resiko hipertensi tidak hanya pola makan, tetapi faktor genetik, usia, obesitas dan pola hidup sehat seperti olahraga. Sebagian besar upaya pengendalian hipertensi sudah baik karena faktor resiko seperti pola makan dapat dikendalikan.

Petugas dan kader kesehatan diharapkan lebih memperhatikan posyandu lansia yang ada di wilayah kerjanya. Pendidikan kesehatan dapat dilakukan untuk meningkatkan pengetahuan lansia tentang hipertensi. Peningkatan pengetahuan diharapkan akan meningkatkan kepatuhan dalam perilaku kesehatan lansia.

\section{DAFTAR RUJUKAN}

Agrina, A., Rini, S. S., \& Hairitama, R. (2011). Kepatuhan Lansia Penderita Hipertensi Dalam Pemenuhan Diet Hipertensi. Sorot, 6(1), 46. https://doi.org/10.31258/sorot.6.1.20 01

Bacha, D., \& Abera, H. (2019). Knowledge, Attitude and Self-Care Practice towards Control of Hypertension among Hypertensive Patients on Follow-up at St. Paul's Hospital, Addis Ababa. Ethiopian Journal of Health Sciences, 29(4), 
421-430.

https://doi.org/10.4314/ejhs.v29i4.2

Cahyawaty, M. I. (2017). Hubungan Dukungan Keluarga dengan Perilaku Lansia Dalam Pengendalian Hipertensi Di Wilayah Puskesmas Pilangkenceng Kabupaten Madiun. Stikes Bhakti Husada Mulia Madiun. Stikes Bhakti Husada Mulia Madiun.

Dalyoko, D. A. P., Kusumawati, Y., \& Ambarwati. (2011). Faktor-Faktor Yang Berhubungan Dengan Kontrol Hipertensi Pada Lansia Di Pos Pelayanan Terpadu Wilayah Kerja Puskesmas Mojosongo Boyolali. Jurnal Kesehatan, 4(1), 201-214.

Heriyadi, Hasballah, K., \& Tahlil, T. (2017). Pengetahuan , Sikap , Dan Perilaku Diet Hipertensi Lansia Di Aceh Selatan Knowledge, Attitude, and Behavior about Hypertension Diet among Elderly in South Aceh. Jurnal Ilmu Keperawatan, 6:1, 5369.

Indonesia, K. K. R. (2018). Laporan nasional Riset Kesehatan Dasar. Jakarta. Retrieved from http://www.depkes.go.id/resources/d ownload/info-terkini/hasil riskesdas2018.pdf

Kemenkes RI. (2018). Laporan Nasional Riskesdas 2018. Badan Penelitian dan Pengembangan Kesehatan. Jakarta.

Kemenkes RI. (2016). Pusat Data dan Informasi Kementerian Kesehatan Republik Indonesia: Situasi Lanjut
Usia (Lansia) di Indonesia. Jakarta: Kementerian Kesehatan RI.

Kemenkes RI. (2013). Pedoman Pengendalian Stroke.

Kuswandono, E. (2019). Hubungan Perilaku Olahraga terhadap Hipertensi pada Lansia di Puskesmas Sidomulyo Pekanbaru. Ensiklopedia of Journal, 1(4), 147152.

Nainggolan, D. F. P., Armiyati, Y., \& Supriyono, M. (2012). Hubungan Dukungan Keluarga dengan Kepatuhan Diit Rendah Garam dan Keteraturan Kontrol Tekanan Darah Pada Penderita Hipertensi di Poliklinik RSUD Tugurejo Semarang. Jurnal Ilmu Keperawtaan Dan Kebidanan, 1(2).

Rahmah, S. (2019). Hubungan Pengetahuan, Sikap Dan Dukungan Keluarga Dengan Keaktifan Kontrol Penderita Hipertensi Di Puskesmas Durian Gantang Kabupaten Hulu Sungai Tengah. Universitas Islam Kalimantan.

Kemenkes RI, K. K. (2018). Situasi Kesehatan Jantung; Mari Menuju Masa Muda Sehat, Hari Tua Nikmat Tanpa PTM dengan Perilaku Cerdik.

Sudoyo, A. W., \& Dkk. (2009). Buku Ajar Penyakit Dalam (5ed ed.). Jakarta: Interna Publising.

Sumarhaeni. (2010). Hubungan Tingkat Pengetahuan Tentang Hipertensi Dengan Upaya Pengendalian 
Hipertensi Pada Lansia Di Puskesmas Saptosari Gunungkidul Yogyakarta. Universitas Jenderal Achmad Yani Yogyakarta.

Sunaryo. (2014). Psikologi untuk Keperawatan. Jakarta: EGC.

Zaenurrohmah, D. H., \& Rachmayanti, R. D. (2017). Hubungan Pengetahuan dan Riwayat Hipertensi dengan Tindakan Pengendalian Tekanan Darah pada Lansia. Jurnal Berkala Epidemiologi, 5(2), 174-184. https://doi.org/10.20473/jbe.v5i2.20 17.174-184 